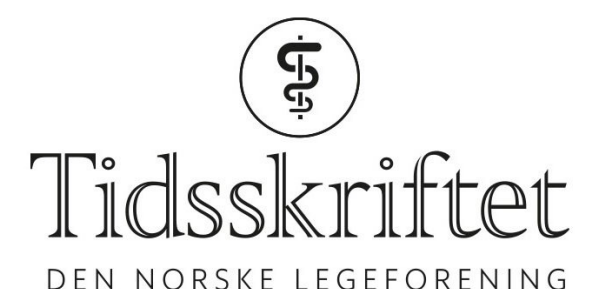

DEN NORSKE LEGEFORENING

\title{
En kvinne i 30-årene med feber av ukjent årsak
}

NOE Å LAERE AV

IDUN BAKKE BØ

E-post: idun.bakke.bo@gmail.com

Medisinsk avdeling

Stavanger universitetssjukehus

Idun Bakke Bø (f. 1983) er lege i spesialisering i generell indremedisin og hematologi og assistentlege ved Lungeseksjonen.

Forfatter har fylt ut ICMJE-skjemaet og oppgir ingen interessekonflikter.

\section{LENE ERIKSON}

Diagnostisk senter

Stavanger universitetssjukehus

Lene Erikson (f. 1981) er lege i spesialisering i generell indremedisin og konstituert overlege.

Forfatter har fylt ut ICMJE-skjemaet og oppgir ingen interessekonflikter.

\section{ANITA SANDMO LYNGØY}

Diagnostisk senter

Stavanger universitetssjukehus

Anita Sandmo Lyngøy (f. 1979) er spesialist i indremedisin og avdelingsoverlege.

Forfatter har fylt ut ICMJE-skjemaet og oppgir ingen interessekonflikter.

\section{SAFA SALEH}

Lungeavdelingen

Stavanger universitetssjukehus

Safa Saleh (f. 1964) er spesialist i indremedisin og lungesykdommer og seksjonsoverlege.

Forfatter har fylt ut ICMJE-skjemaet og oppgir ingen interessekonflikter.

Feber av ukjent årsak kan være en diagnostisk utfordring, særlig når symptomer og tegn er uspesifikke og undersøkelser ikke avdekker objektive funn. Vår pasient hadde tidligere gjennomgått ulike operative inngrep. Dette bidro til å gjøre utredningen langvarig og omfattende før man kunne konkludere med en diagnose.

En kvinne i zo-årene ble innlagt i medisinsk avdeling med spørsmål om infeksjon. De siste ni dagene hadde hun hatt høy feber, $39-40^{\circ} \mathrm{C}$, nedsatt allmenntilstand, generelle smerter i kroppen og frostanfall. Det var ingen symptomer fra luft- eller urinveier. Fra tidligere hadde hun migrene, endometriose og adenomyose. Hun hadde gjennomgått laparoskopisk hysterektomi og tubektomi pga. endometriose et halvt år tidligere. I etterkant hadde hun periodevis vært plaget med smerter i relasjon til blære og urinretensjon. Hun brukte fast amitriptylin mot tensjonshodepine, buprenorfin og paracetamol mot endometriosesmerter, metenaminhippurat forebyggende mot urinveisinfeksjon samt 
tramadol og ibuprofen ved behov. Det forelå malignt melanom og pancreascancer hos førstegradsslektninger, men ellers var det ingen relevante sykdommer i familien. Det var ingen opphopning av immunologiske lidelser.

Ved klinisk undersøkelse var det normale funn, med unntak av lett palpasjonsømhet over blære og bankeømhet over høyre nyrelosje, noe hun anga var habituelt. Pasienten var afebril, og det var stabile vitale tegn (blodtrykk, puls, $\mathrm{O}_{2}$-metning). Det var negativ urinstiks og normal urinmikroskopi. Blodprøver viste leukocytter 3,2 $\bullet 10^{9} / 1\left(3,5-8,8 \bullet 10^{9} / \mathrm{l}\right)$ og CRP $13 \mathrm{mg} / \mathrm{l}(<5 \mathrm{mg} / \mathrm{l})$. De øvrige orienterende blodprøver var normale, inkludert senkning $14 \mathrm{~mm} / \mathrm{t}(<20 \mathrm{~mm} / \mathrm{t})$. Røntgen thorax ble beskrevet som negativt, og ultralydunders $\emptyset$ kelse av nyrer og urinveier var uten patologiske funn.

Pasienten hadde ikke vært utenlands det siste året. Primært mistenkte man infeksjon, med mest sannsynlig fokus i urinveier. Hun hadde imidlertid lave infeksjonsmarkører og normale urinfunn.

Urinstiks og mikroskopi ble gjentatt og var fortsatt negative. Pasienten ble vurdert av gynekolog, uten nye funn. Urolog fant normale funn ved cystoskopi og ingen resturin.

På grunn av mangel på sikkert infeksjonsfokus og fortsatt høyfebril pasient ble det gjort bredere diagnostikk med tanke på immunologisk sykdom, malignitet og infeksjoner.

Serologiske prøver for cytomegalovirus, Epstein-Barr-virus, parvovirus B19, hiv, syfilis og borrelia, nasopharynx-PCR med tanke på luftveispatogener, blodkulturer, stoffskifteprøver, immunoglobuliner, immunologiske prøver og kreftmarkørene CEA (karsinoembryonalt antigen) og CA125 (cancerantigen 125) var alle negative. Kontroll av generelle blodprøver etter to dager viste laktatdehydrogenase $214 \mathrm{U} / \mathrm{l}(103-213 \mathrm{U} / \mathrm{l}$ ) og albumin 33,5 g/l (36-48 g/l), de øvrige var upåfallende. CRP- og leukocyttnivå var normalisert.

Etter tre dager i sykehus hadde man fortsatt ingen avklaring når det gjaldt pasientens symptomer. Hun hadde gjentatte episoder med høy feber, $39-40{ }^{\circ} \mathrm{C}$ rektalt. Supplerende bildediagnostikk med ultralyd av abdomen var uten patologiske funn.

Dag 5 etter innleggelsen var det hevelse i høyre mamma, mammae var ikke blitt undersøkt ved innkomst. Noen uker i forkant av innleggelsen hadde kvinnen hatt samme symptomer rundt høyre mamma, som da hadde gått spontant tilbake. Ved nærmere anamnese kom det frem at pasienten hadde fått operert inn brystimplantater da hun var i 2o-årene. Senere var hun blitt reoperert på grunn av kapseldanning rundt implantatene. Hun hadde også fått injisert Restylane (hyaluronsyregel) i leppene 5-7 år tidligere. Ultralyd mammae viste et anekkoisk væskelokulament rundt høyre protese.

Kunne væsken ha sammenheng med feberen? Funnet var ikke typisk for proteselekkasje eller abscess. Ved proteselekkasje ville man forvente høyere ekkosignal og ved abscess fnokket utseende på væsken.

Pasienten ble diskutert tverrfaglig med infeksjonsmedisiner, klinisk immunolog og plastikkirurg. Man overveide om det kunne være en lavvirulent mikrobe og at væsken kunne være reaktiv. Ved en viral infeksjon ville man forventet bilateral reaktiv affeksjon av protesene.

Plastikkirurgen gjorde en diagnostisk tapping. Direktemikroskopi av gram- og akridinfargede preparater ble besvart negativt, og det var ingen oppvekst av bakterier ved dyrking. Akridinfarging er en fluorescensteknikk som blant annet kan brukes til å påvise bakterielt DNA. Materialet ble ikke sendt til cytologisk undersøkelse. Fremdeles hadde vi ingen funn som kunne forklare feberen. Kvinnen ble utskrevet i påvente av svar på prøvene to uker etter symptomdebut.

Tre dager senere ble hun reinnlagt med høy feber, $39-40{ }^{\circ} \mathrm{C}$ rektalt, nedsatt allmenntilstand og hodepine. Det var ingen nye funn siden forrige undersøkelse. Orienterende blodprøver var fortsatt normale.

Pasienten ble på ny diskutert tverrfaglig med infeksjonsmedisiner og immunolog. Det ble anbefalt gastroskopi for å utelukke Whipples sykdom, som kan være en 
differensialdiagnostisk mulighet ved feber og uspesifikke magesmerter.

Ekkokardiografi ble rekvirert med tanke på endokarditt, og hun ble henvist til CTundersøkelse av abdomen og bekken for å utelukke komplikasjoner etter tidligere operasjoner i underlivet.

Ved undersøkelsene var det normale funn. Duodenalbiopsiene var uten funn av noe signifikant patologisk.

Fire uker etter symptomdebut var det, til tross for bred diagnostikk, ingen holdepunkter for infeksjon, immunologisk sykdom eller malignitet.

Medikamentfeber var også en aktuell differensialdiagnose, og aktuelle medikamenter (amitriptylin og metenaminhippurat) ble prøveseponert. Etter dette ble det målt noe lavere temperaturer, men pasienten hadde fortsatt feber. Hun følte seg imidlertid litt bedre. Hun ble igjen utskrevet, og det var planlagt snarlig poliklinisk kontroll.

To dager senere rapporterte pasienten om høy feber og uttalt nattesvette - hun hadde måttet skifte sengetøy midt på natten.

Det var $ø$ kende smerter i høyre bryst og $\emptyset$ mhet i begge aksiller, men infeksjonsmarkørene var normale. Høyre bryst var lett forstørret, men det var verken rubor, varme eller erytem. Hun var palpasjonsøm i høyre aksille, men hadde ingen palpable lymfeknuter.

På bakgrunn av pasientens symptomer med nattesvette og ømhet i aksille ble det rekvirert CT collum og thorax.

CT thorax viste forstørrede lymfeknuter i mediastinum og lungehili (fig 1 ).

Angiotensinkonverterende enzym (ACE) var lett forhøyet, til $85 \mathrm{U} / \mathrm{l}(<60 \mathrm{U} / \mathrm{l})$.

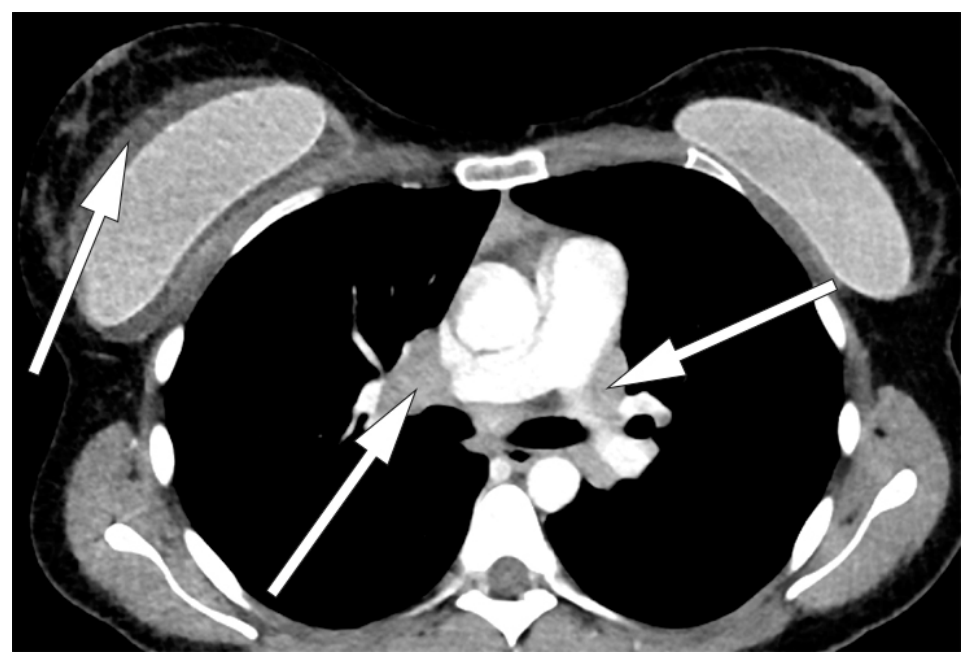

Figur 1 CT thorax med intravenøs kontrast, sagittalsnitt. I høyre hilus ses lymfeknutekonglomerat som måler $3 \mathrm{~cm}$. Tilsvarende lymfeknutekonglomerat ble sett prekarinalt (ikke på bildet). Bilaterale brystimplantater. Rundt høyre ses vceskebrem omkring implantetet

Det ble utført bronkoskopi med endobronkial ultralyd (EBUS), hvor

finnålsaspirasjonscytologi, FNAC) fra mediastinal lymfeknute viste granulomatøs betennelse uten nekrose.

Radiologisk kunne funnene være forenlig med sarkoidose. Forhøyet ACE-nivå og funn av granulomatøs betennelse styrket mistanken. De kliniske funn var likevel ikke helt typisk for sarkoidose. Vanligste presentasjon ved affeksjon av lunger er hoste, dyspné og brystsmerter, som ofte kan følges av slapphet, sykdomsfølelse, feber og vekttap. Vår pasient hadde ingen symptomer fra luftveiene.

Det er publisert flere kasusistikker om silikonimplantatindusert lymfadenopati (1), også hos pasienter som ikke har symptomer på proteseruptur. Vanligst er lokale symptomer over brystprotesen, hoste, lymfadenopati, nedsatt allmenntilstand og feber. Biopsi hos disse pasientene har vist klassisk granulomatøs betennelse og kjempecellereaksjon (1). 
Hos vår pasient så man granulomatøs betennelse, men ikke kjempeceller. Det var ikke tilstrekkelig/egnet materiale til å undersøke FNAC-prøven med tanke på silikon i lymfeknuten.

Siden sykdomsdebuten seks uker tidligere hadde pasienten hatt feber på $39-40{ }^{\circ} \mathrm{C}$ nesten daglig. De siste to uker hadde hun periodevis hatt nattesvette som nødvendiggjorde skifte av sengetøy. Hun hadde gått ned $8 \mathrm{~kg}$ på seks uker.

Under hele forløpet var det normal laktatdehydrogenase. Ut fra bildediagnostikk syntes lymfom å være mindre sannsynlig, men med bakgrunn i utvikling av uttalte B-symptomer (feber, vekttap og nattesvette) ble det gjort benmargsbiopsi.

Litteraturen beskriver også sjeldne tilfeller av lokalisert T-cellelymfom assosiert med silikonbrystimplantater (2-6).

Benmargsbiopsi viste normal hematopoese. Det var ingen atypiske infiltrater, og det ble ikke påvist granulomer. Det var heller ingen tegn til atypi/malignitet.

CT-undersøkelse og ultralyd mammae var begge beskrevet som negative med tanke på proteseruptur. Litteraturen beskriver at MR-undersøkelse er foretrukket modalitet, mer sensitiv og spesifikk enn ultralyd- og CT-undersøkelse for å påvise ruptur (1).

MR mammae ga mistanke om proteseruptur, og man så tegn til silikon i aksillære lymfeknuter bilateralt. Mediastinale lymfeknuter kunne ikke vurderes på MR mammae (fig 2 , fig 3$)$.

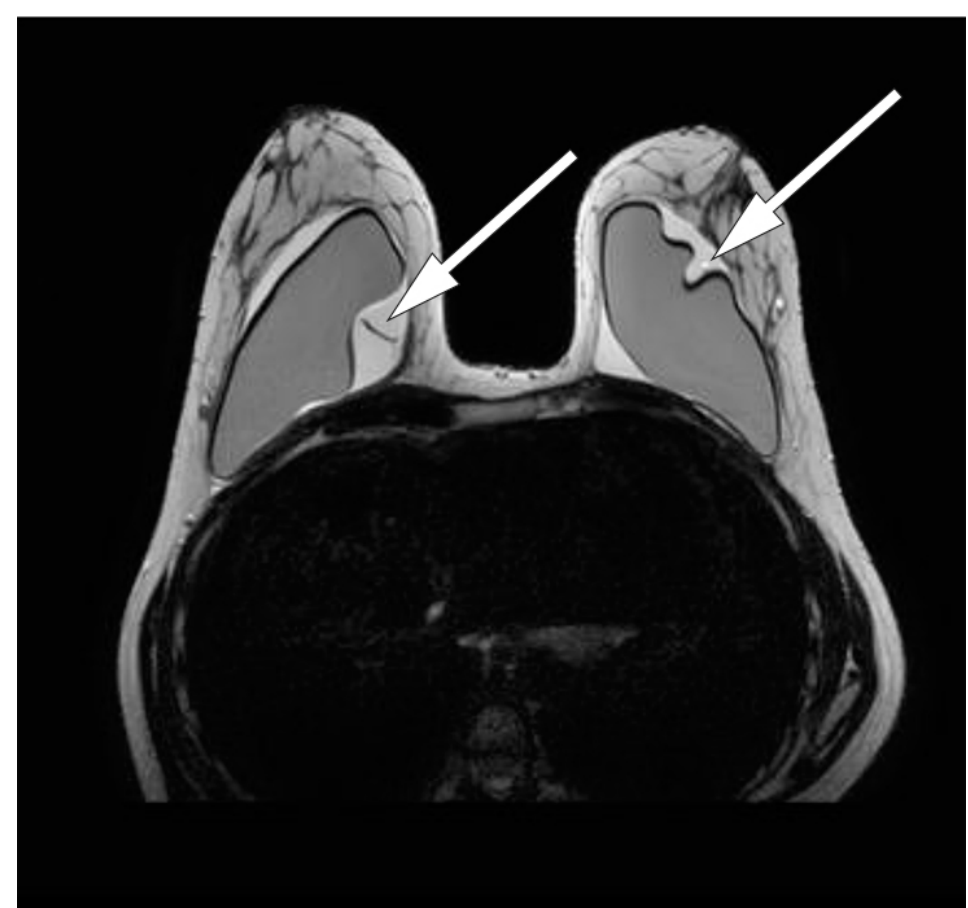

Figur 2 MR mammae, T2-vektet serie. Mistanke om proteseruptur bilateralt. En god del vceske omkring implantatene bilateralt 


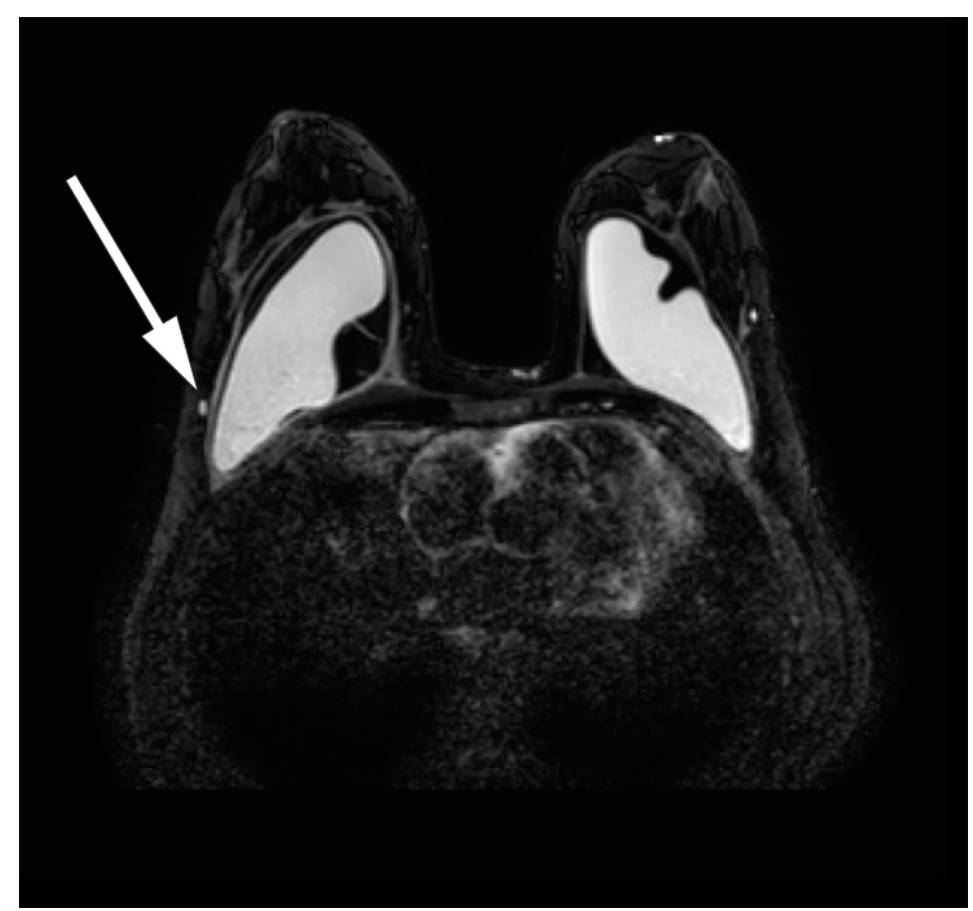

Figur 3 MR mammae, «silicon only»-serie. Mistanke om små mengder silikon i aksillare lymfeknuter

Pasienten fikk nå, syv uker etter debuten, fjernet protesene kirurgisk. Begge var tilsynelatende intakt. Makroskopisk så man fortykket kapsel rundt høyre protese, og det var rikelig med serøs væske mellom kapsel og protese.

Pasienten ble igjen diskutert tverrfaglig med lungelege, hematolog og immunolog. Hennes tilstand kunne dreie seg om sarkoidose, immunologisk reaksjon på silikon eller lymfom (storcellet anaplastisk lymfom).

Man besluttet å avvente svar på histologiske prøver fra implantatkapslene før man gjorde mediastinoskopi for å sikre histologisk prøve fra mediastinal lymfeknute - dette for sikkert å utelukke lymfom. Behandlingsfors $\emptyset \mathrm{k}$ med prednisolon ble utsatt til dette var sikret. Tre induserte sputumprøver med tanke på tuberkulose var negative.

Cytologisk prøve av væsken fra høyre mamma viste uspesifikk kronisk inflammasjon. Det var ingen holdepunkter for malignitet. Undersøkelse av operasjonspreparatet viste fortykket kapsel på høyre side og noe tynnere på venstre. Det var ingen tegn til proteseruptur. Histologisk prøve fra kapselen viste granulomatøs betennelse uten nekrose og utvaskede hulrom i makrofager, forenlig med forekomst av silikon (fig 4 , fig 5 ).

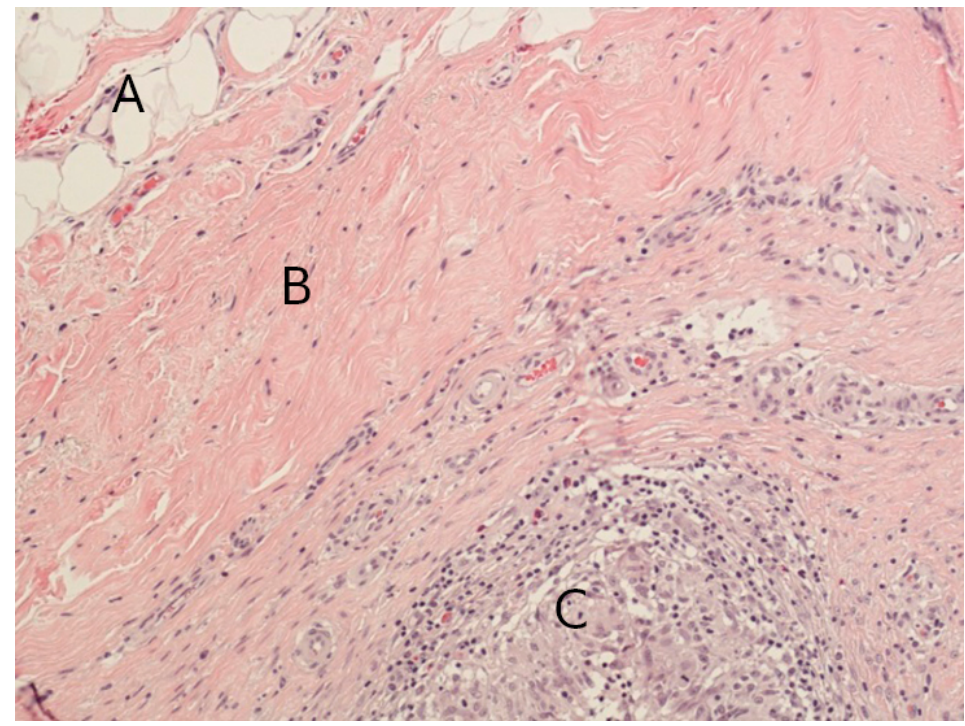

Figur 4 Snitt gjennom protesekapsel høyre side: fettvev (A), bindevev (B), granulomer (C).

Mikroskopisk ses i samtlige snitt fra begge protesekapsler bindevev med granulomatøs betennelse uten nekroser 


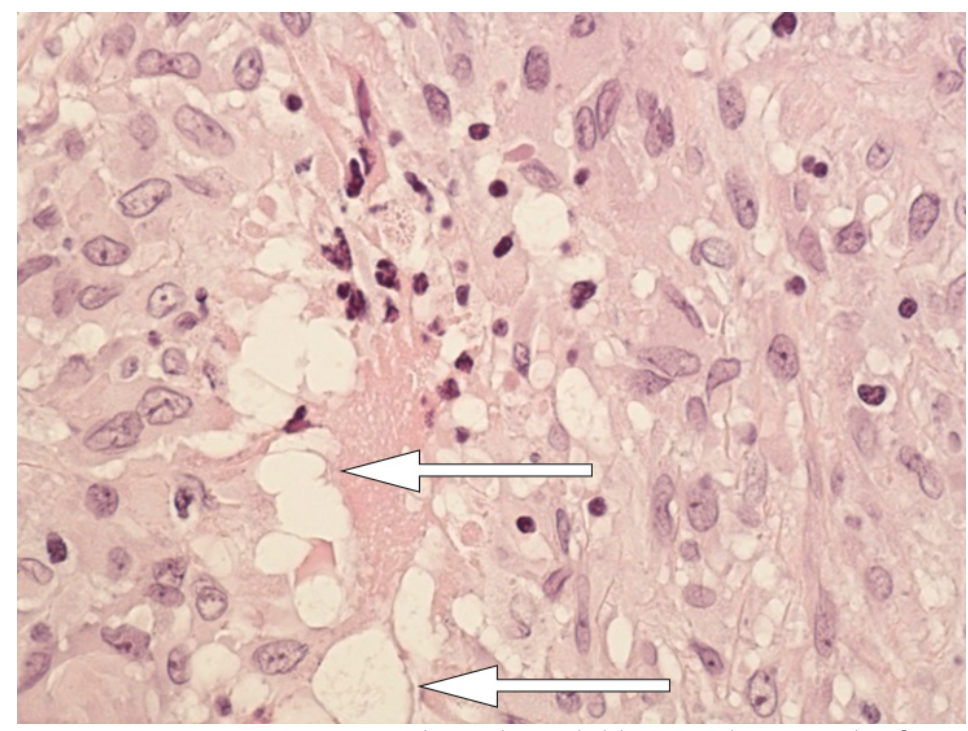

Figur 5 Snitt gjennom protesekapsel: ncerbilde granulom. I makrofagene er der forandringer i form av utvaskede hulrom, forenlig med forekomst av silikon (pil)

Før man fikk utført mediastinoskopi, ni uker ut i forløpet, utviklet pasienten kraftig global hodepine. Samtidig utviklet hun perifer facialisparese på venstre side og hadde episoder med konfusjon. Klinisk undersøkelse tydet på affeksjon av både venstre $n$. facialis perifert og n. trigeminus.

Både lymfom og sarkoidose kan gi facialisparese - lymfom helst som ledd i mer generalisert perifer polynevropati, sjeldnere er isolert facialisparese (7). Vanligste nevrologiske funn ved sarkoidose er perifer facialisparese. Det aktuelle utfallet kunne tale for sarkoidose.

MR caput viste at det var kommet til kontrastladende vev i cavum trigeminale bilateralt. Det ble stilt spørsmål om dette kunne være en manifestasjon av sarkoidose. De kliniske funn passet godt med MR-funnene, bortsett fra at pasienten kun hadde symptomer på venstre side. Spinalvæsken var negativ med tanke på virus (herpes simplex-virus 1 og 2, varicella zoster, enterovirus og nevroborreliose), og det var heller ikke oppvekst av bakterier (negativt funn ved direkte mikroskopi).

Ti uker var gått siden første symptom meldte seg. Man mistenkte nå at sarkoidose var den mest sannsynlige diagnosen. Etter tverrfaglig diskusjon besluttet man at endelig histologiske prøver likevel måtte sikres før behandlingsforsøk. Planlagt medistinoskopi ble derfor gjennomført.

Biopsier fra lymfeknute i mediastinum var tettpakket med ikke-nekrotiserende granulomer, forenlig med sarkoidose. Det var ikke tegn til lymfom eller silikon (fig 6).

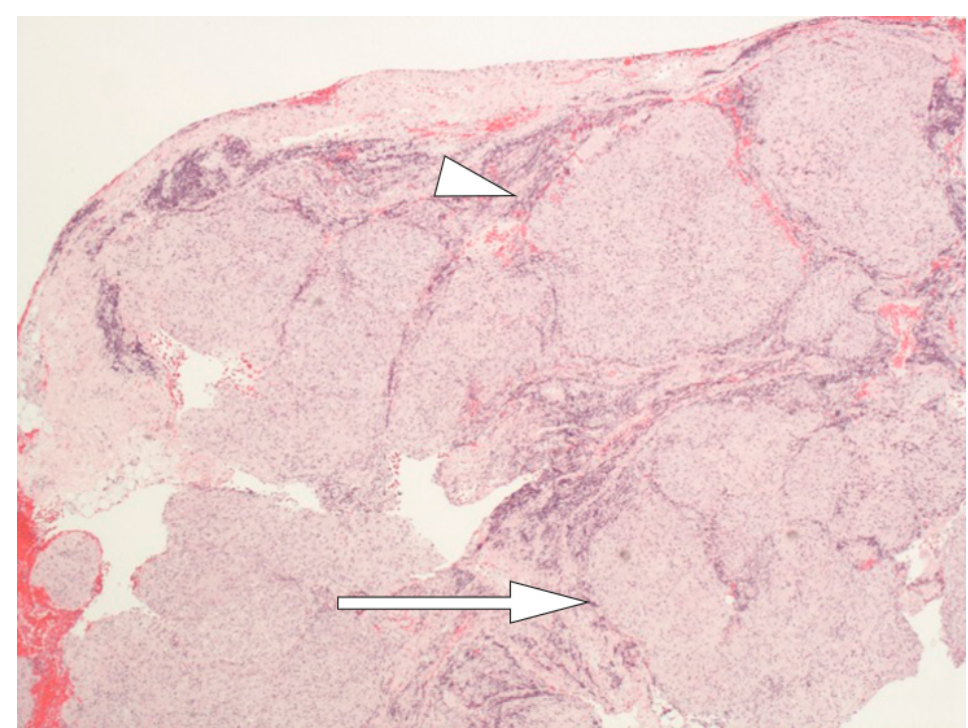

Figur 6 Oversikt lymfeknute med granulomatøs betennelse: tettpakket med ikke-nekrotiserende 
velformede epiteloidcellegranulomer (pil), alle med lignende utseende og modningsgrad med smal brem av lymfocytter perifert som såkalt nakne granulomer (pilhode). Ikke holdepunkter for silikonindusert lymfadenopati. Morfologisk bildet kan passe med sarkoidose

I litteraturen beskrives spektrometri og elektronmikroskopi som gullstandard for påvisning av silikon (1). Disse undersøkelsene er ikke tilgjengelige ved vårt laboratorium. Vi konkluderte med at diagnosen mest sannsynlig var systemisk sarkoidose.

11 uker etter symptomdebut startet pasienten behandling med prednisolon og Solu-medrolstøt, senere oppstart med Cellcept.

Ved kontroll etter tre uker hadde hun mer overskudd. Det var ingen feber eller nattesvette. Facialisparesen var i bedring. Smertebehandlingen var trappet betydelig ned. Pasienten følges opp videre ved immunologisk avdeling.

\section{Diskusjon}

Vår pasient presenterte ikke klassiske symptomer på sarkoidose, og det ble gjort flere diagnostiske overveielser underveis. På grunn av kort sykehistorie ble det initialt satt søkelys på infeksjon som sannsynlig årsak til plagene. Etter hvert som tiden gikk og det ble flere symptomer og pasienten ble stadig dårligere uten at man hadde noen diagnose, ble bredere diagnostikk iverksatt.

Et histologisk bilde med ikke-nekrotiserende granulomer (sarkoidreaksjon) kan forekomme ved sarkoidose, malignitet og infeksjoner. Sarkoidose er en immunologisk multisystemsykdom som gir en patologisk reaksjon med granulomdanning på ukjent antigen. Flere agenser kan være aktuelle.

Til tross for utstrakt forskning er den utløsende årsak til sarkoidose ikke kjent (8). Vanlige symptomer er hoste, dyspné og brystsmerter, ofte sammen med utmattelse, vekttap og feber $(9,10)$. Prevalensen er 10-20 per 100 ooo per år, og som oftest er unge voksne affisert (11).

Granulomatøs betennelse kan også ses ved migrasjon av silikon fra brystimplantater (1). Silikon er muligens assosiert med en immunologisk reaksjon kalt ASIA-syndrom (adjuvansindusert autoimmunt/inflammatorisk syndrom, «autoimmun/inflammatory syndrom introduced by adjuvants») (9). Lokalisert lymfom i protesekapsel, anaplastisk storcellet T-cellelymfom (ALCL) er beskrevet ved lignende kliniske manifestasjoner som hos vår pasient (2-6).

Ved gjennomgang av litteraturen finner vi flere pasienthistorier der lymfadenopati og granulomatøs betennelse hos kvinner med brystproteser beskrives. I en kasusserie med 18 pasienter fra Mayo-klinikken beskrives et lignende symptombilde som hos vår pasient feber, nedsatt allmenntilstand, fokale symptomer over implantatet og lymfadenopati i aksiller og hilært. 34\% hadde symptomer på proteseruptur, resten var asymptomatiske (1).

Silikon som migrerer utenfor brystet, initierer inflammasjon og granulomdanning (12). Det vanligste er migrasjon til aksillære lymfeknuter. Lymfedrenasje fra brystet skjer gjennom tre hovedruter: aksillære, transpektorale og indre mammilære lymfebaner (13). Silikonmigrasjon kan skje langs disse banene, men kan også spres retrograd eller langs andre baner (14). Sjeldne tilfeller av pneumonitt er også observert (15-17).

Shoenfeld \& Agmon-Levin omtaler det nye ASIA-syndromet, som utløses av fremmedlegemer. Blant annet silikon antas å kunne trigge immunologisk sykdom (18). Syndromet eksistens er omdiskutert $(19,20)$.

Vi finner flere kasuistikker der granulomatøs betennelse og kutan sarkoidose etter injeksjon av silikonpreparater i kosmetisk øyemed beskrives (21-25). Det er også beskrevet remisjon av antatt sarkoidose etter fjerning av silikonbrystimplantater (26). Det er vist at silikon indusere autoimmunitet i ulike dyremodeller (27), men man har ikke funnet noen sikker sammenheng mellom autoimmunitet og silikonproteser hos mennesker (19, 20, 28, 29). 
Påvist silikon i vev eller granulomer utelukker ikke diagnosen sarkoidose (25).

Vi kan ikke konkludere med at silikonprotesene hadde betydning for vår pasient. Hun hadde granulomatøs betennelse i forbindelse med protesen - utvaskede hulrom som tegn på silikonlekkasje, funn av antatt silikon i aksillære lymfeknuter på MR-undersøkelse og fokale symptomer som kan indikere en sammenheng. Det som peker i retning av systemisk sarkoidose, er affeksjon av sentralnervesystemet og at det heller ikke ble funnet tegn til kjempeceller eller silikon i mediastinale glandler.

Vi konkluderer med diagnosen systemisk sarkoidose, men silikonprotesenes rolle i sykdomsbildet forblir usikker.

\section{LITTERATUR:}

1. Bauer PR, Krajicek BJ, Daniels CE et al. Silicone breast implant-induced lymphadenopathy: 18 Cases. Respir Med CME 2011; 4: 126 - 30. [CrossRef]

2. de Jong D, Vasmel WL, de Boer JP et al. Anaplastic large-cell lymphoma in women with breast implants. JAMA 2008; 300: 2030 - 5. [PubMed][CrossRef]

3. Ferreri AJ, Govi S, Pileri SA et al. Anaplastic large cell lymphoma, ALK-negative. Crit Rev Oncol Hematol 2013; 85: 206 - 15. [PubMed][CrossRef]

4. Laurent C, Delas A, Gaulard P et al. Breast implant-associated anaplastic large cell lymphoma: two distinct clinicopathological variants with different outcomes. Ann Oncol 2016; 27:306 - 14. [PubMed][CrossRef]

5. Letter H, Rop B, Edison MN et al. Breast Implant-Associated Anaplastic Large Cell Lymphoma: A Case Report and Literature Review. Cureus 2016; 8: e546. [PubMed]

6. Rupani A, Frame JD, Kamel D. Lymphomas Associated with Breast Implants: A Review of the Literature. Aesthet Surg J 2015; 35: 533 - 44. [PubMed][CrossRef]

7. Kelly JJ, Karcher DS. Lymphoma and peripheral neuropathy: a clinical review. Muscle Nerve 2005; 31: 301 - 13. [PubMed][CrossRef]

8. Newman LS, Rose CS, Maier LA. Sarcoidosis. N Engl J Med 1997; 336: 1224 - 34. [PubMed][CrossRef]

9. Caldeira M, Ferreira AC. Siliconosis: autoimmune/inflammatory syndrome induced by adjuvants (ASIA). Isr Med Assoc J 2012; 14: 137 - 8. [PubMed]

10. Ungprasert P, Carmona EM, Utz JP et al. Epidemiology of Sarcoidosis 1946-2013: A Population-Based Study. Mayo Clin Proc 2016; 91: 183 - 8. [PubMed][CrossRef]

11. Thomas KW, Hunninghake GW. Sarcoidosis. JAMA 2003; 289:3300 - 3. [PubMed][CrossRef]

12. Smalley DL, Shanklin DR, Hall MF et al. Immunologic stimulation of T lymphocytes by silica after use of silicone mammary implants. FASEB J 1995; 9: 424 - 7. [PubMed]

13. Sharma A, Fidias P, Hayman LA et al. Patterns of lymphadenopathy in thoracic malignancies. Radiographics 2004; 24: 419-34. [PubMed][CrossRef]

14. Kaufman GJ, Sakr RA, Inguenault C et al. Silicone migration to the contralateral axillary lymph nodes and breast after highly cohesive silicone gel implant failure: a case report. Cases J 2009; 2: 6420. [PubMed][CrossRef]

15. Dragu A, Theegarten D, Bach AD et al. Intrapulmonary and cutaneous siliconomas after silent silicone breast implant failure. Breast J 20o9; 15: 496 - 9. [PubMed][CrossRef]

16. Paredes Vila S, Gonzalez Barcala FJ, Suarez Antelo J et al. Pneumonitis caused by silicone gel following breast implant rupture. Ir J Med Sci 2010; 179: 141 - 5. [PubMed][CrossRef]

17. Chang KC, Chan KT, Chong LY et al. Cutaneous and pulmonary sarcoidosis in a Hong Kong Chinese woman with silicone breast prostheses. Respirology 2003; 8: 379 - 82. [PubMed][CrossRef]

18. Shoenfeld Y, Agmon-Levin N. 'ASIA' - autoimmune/inflammatory syndrome induced by adjuvants. J Autoimmun 2011;36: 4 - 8. [PubMed][CrossRef] 
19. Hajdu SD, Agmon-Levin N, Shoenfeld Y. Silicone and autoimmunity. Eur J Clin Invest 2011; 41: 203 -

11. [PubMed][CrossRef]

20. Hölmich LR, Lipworth L, McLaughlin JK et al. Breast implant rupture and connective tissue disease: a review of the literature. Plast Reconstr Surg 2007; 120: 62S - 9S. [PubMed][CrossRef]

21. Antonovich DD, Callen JP. Development of sarcoidosis in cosmetic tattoos. Arch Dermatol 2005; 141: 869 - 72. [PubMed][CrossRef]

22. Hariri LP, Gaissert HA, Brown R et al. Progressive granulomatous pneumonitis in response to cosmetic subcutaneous silicone injections in a patient with HIV-1 infection: case report and review of the literature. Arch Pathol Lab Med 2012; 136: 204 - 7. [PubMed][CrossRef]

23. Descamps V, Landry J, Francès C et al. Facial cosmetic filler injections as possible target for systemic sarcoidosis in patients treated with interferon for chronic hepatitis C: two cases. Dermatology 2008; 217: 81 - 4. [PubMed][CrossRef]

24. Marcoval J, Mañá J, Moreno A et al. Foreign bodies in granulomatous cutaneous lesions of patients with systemic sarcoidosis. Arch Dermatol 2001; 137: 427-30. [PubMed]

25. Callen JP. The presence of foreign bodies does not exclude the diagnosis of sarcoidosis. Arch Dermatol 2001; 137: 485-6. [PubMed]

26. Teuber SS, Howell LP, Yoshida SH et al. Remission of sarcoidosis following removal of silicone gel breast implants. Int Arch Allergy Immunol 1994; 105: 404 - 7. [PubMed][CrossRef]

27. Vera-Lastra O, Medina G, Cruz-Dominguez MP et al. Autoimmune/inflammatory syndrome induced by adjuvants (Shoenfeld's syndrome): clinical and immunological spectrum. Expert Rev Clin Immunol 2013; 9:361 - 73. [PubMed][CrossRef]

28. Bar-Meir E, Eherenfeld M, Shoenfeld Y. Silicone gel breast implants and connective tissue disease-a comprehensive review. Autoimmunity 2003;36: 193 - 7. [PubMed][CrossRef]

29. Janowsky EC, Kupper LL, Hulka BS. Meta-analyses of the relation between silicone breast implants and the risk of connective-tissue diseases. N Engl J Med 2000; 342: 781 - 9o. [PubMed][CrossRef]

Publisert: 18. september 2017. Tidsskr Nor Legeforen. DOI: 10.4045/tidsskr.17.0019

Mottatt 4.1.2017, første revisjon innsendt 30.4.2017, godkjent 27.6.2017.

(C) Tidsskrift for Den norske legeforening 2020. Lastet ned fra tidsskriftet.no 